\title{
Research on Creative Transformation and Innovative Development of Red Culture Taking Wuhan Revolutionary Museum as an Example
}

\author{
Shijing Xiao ${ }^{1, *}$
}

${ }^{1}$ Wuhan Revolutionary Museum, Wuhan, Hubei, China

*27485610@qq.com

\begin{abstract}
Red culture needs creative transformation and innovative development to adapt to the growing social needs. Wuhan Revolutionary Museum has been constantly exploring new development directions in the innovation of red culture communication path, the innovation of red culture exhibition planning content and form, the innovation of red culture collection, protection and utilization. We must study and sum up the history of the Communist Party of China, pass on and carry forward the Successful experience of the Communist Party of China, and enable the Communist Party of China members, cadres and ordinary citizens to draw valuable experience and spiritual strength from reviewing the Glorious history of the Communist Party of China, so as to study history with a clear understanding, enhance trust, worship morality, and put it into practice. Red is the base color of the Communist Party of China, the base color of the Chinese Dream, and the base color of the Revolutionary Museum. Wuhan Revolutionary Museum will also continue to carry forward the red culture and inherit the red gene, and build the museum into a new highland of red culture in the new era.
\end{abstract}

Keywords: red culture, innovation, development

\section{红色文化的创造性转化和创新性发展研究 以武汉革命博物馆为例}

\author{
肖诗静 1 , *
}

'武汉革命博物馆, 武汉, 湖北, 中国

*27485610@qq.com

\section{内容提要}

红色文化需要创造性转化和创新性发展来适应日益增长的社会需求。武汉革命博物馆在红色文化传播路径的创 新、红色文化展览策划内容和形式的创新、红色文化藏品征集保护利用形式的创新等方面一直不断探索寻求新 的发展方向。我们要把党的历史学习好、总结好, 把党的成功经验传承好、发扬好, 让广大党员干部和人民群 众在重温党的光辉历史中汲取宝贵经验和精神力量, 做到学史明理、学史增信、学史崇德、学史力行。红色, 是中国共产党的底色, 也是中国梦的底色, 是革命博物馆的底色。武汉革命博物馆也将继续弘扬红色文化, 传 承红色基因，将博物馆打造成为新时代红色文化的新高地。

关键词: 红色文化 创新 发展 


\section{1. 前言}

今年是中国共产党成立一百周年, 红色旅游成为出 游的主旋律。红色旅游是具有中国特色的旅游形式, 目 前发展势头强劲, 新线路、新玩法不断涌现, 与生态游、 民俗游、研学游、乡村游等深度融合, 形成旅游新业态。 各地围绕建党百年深挖红色文化内涵, 丰富红色旅游产 品, 更好满足人民群众的红色旅游需求, 推动红色旅游 发展, 更好传承红色基因。红色旅游不是单纯的旅游产 品, 而是肩负着传播红色革命精神的教育功能, 是通过 丰富多彩的旅游产品把伟大历史记忆和红色基因融入 广大群众的血脉之中; 通过讲好红色故事, 特别是结合 重大历史事件、重要历史人物, 深入挖掘革命文物内涵 传播红色文化精神, 通过革命先辈的故事充实丰富红色 旅游内容, 让爱国主义精神和优良传统作风深入人心 [1]。党的十八大以来, 博物馆免费开放深入推进, 文 物保护能力日益加强, 公共服务效能显著提升, 社会影 响力不断提高。“十三五” 期间, 全国博物馆数量由 4692 家增长至 5788 家, 平均每两天就有一家博物馆建成开 放; 博物馆年度参观人数由 7 亿人次增长至 12 亿人次, 平均每年增加 1 亿人次; 未成年人观众数量由每年 2.2 亿人次增长至 2.9 亿人次。博物馆在经济社会发展中的 作用持续显现, 给人民群众带来的获得感、幸福感不断 增强, 已经成为人民向往的美好生活的一部分。

纪念馆是博物馆大家庭的重要组成部分, 主要是纪 念革命运动中的重大历史事件或具有重大贡献的历史 人物的一种文化教育事业机构。纪念馆承担了红色文化 的传播功能。观众到纪念馆参观既享受了纪念馆良好的 服务又接受了爱国主义教育。现在全国有 581 家中小学 研学实践教育基地中, 有 203 家是博物馆纪念馆, 约占 35\%, 基本形成了全国博物馆研学实践活动的阵地网络。 红色文化需要创造性转化和创新性发展来适应日益增 长的社会需求。武汉革命博物馆在红色文化传播路径的 创新、红色文化展览策划内容和形式的创新、红色文化 藏品征集保护利用形式的创新等方面一直不断探索寻 求新的发展方向。

\section{2. 红色文化传播路径的创新一一数字博物馆 建设}

在武昌黄鹤楼下, 距离户部巷北边的不远处, 有一 条 417 米的青石小路, 它就是武昌都府堤, 也被称为 “中 国第一红街”。都府堤原是清朝修筑在武昌古城司湖边 的堤坝, 由于靠近都察院御史府的衙门, 晚清又逐渐沿 堤形成了居民区, 就此命名为都府堤大街。尽管只有短 短几百米, 都府堤却不是一个简单角色。这条街由南至 北, 拥有武昌中央农民运动讲习所、毛泽东旧居、中共 五大会址纪念馆、中国共产党纪律建设历史陈列馆四处 红色旅游经典景区。他们都是武汉革命博物馆下辖的革 命旧址和红色场馆。

武汉革命博物馆现为国家一级博物馆、全国重点文 物保护单位、全国爱国主义教育示范基地、全国廉政教 育基地、全国百个红色旅游经典景区，年接待观众 223
万人次以上, 每年举办、引进、输出展览 10 多个, 举 办社教活动 50 余次。博物馆现已成为征集、收藏、保 护、研究武汉地区近现代文物、革命文物、党史文物和 展示大革命史、中共党史及重大历史事件的综合性博物 馆, 更是大革命史和武汉地区党史的研究中心。是武汉 地区红色景点最多、内涵最丰富、资源保护最早、知名 度最高的红色旅游资源富集区, 现已成为全面从严治党 的圣地、纪律教育的基地和红色旅游的胜地。

联合国科教文组织最近报告, 受疫情影像, 2020 年 全球有 $84 \%$ 的博物馆处于闭馆状态，平均闭馆时间达 155 天, 参观人数与 2019 年相比平均下降 $70 \%$, 收入减 少 40\%-60\%。科教文组织还建议: 各国应进一步增加对 博物馆的公共财政支持、加强数字能力建设，不断强化 博物馆的教育和社会功能 [2]。博物馆的转型复苏是当 前全球博物馆的共性问题。疫情以来，公共文化通过数 字化服务, 得到了广大民众的欢迎, 推进博物馆大数据 体系建设, 大力发展博物馆的云展览、云教育, 构建线 上线下相融合的博物馆传播体系是未来博物馆发展的 方向。

武汉革命博物馆在数字博物馆建设上一直不断探 索创新。为打造体验式红色文旅融合发展新模式，今年 的 “ 5 - 18” 国际博物馆日在我馆开展了 “武汉 1927 ” 沉浸式思政课暨百年党史学习教育主题活动, 为观众上 了一堂特殊的沉浸式思政课。这是一次全新的尝试, 在 革命旧址通过沉浸式、接地气、有温度的情景党课，还 原 1927 年那段峥嵘岁月, 100 名观众在武汉革命博物馆 和长江人民艺术剧院的社教老师带领下，化身为革命志 士, 深度体验, 互动演绎 [3]。在武昌农讲所, 情景党 课《历史的回望》，将农讲所的一天的学习生活情况真 实再现，“军事教官” 带领 “农讲所学员” 举行军事操 练, 高唱《国际歌》, 引领观众一同追忆早期无产阶级 革命前辈不畏艰险、慷慨激昂的峥嵘岁月。

2019 年 12 月, 我馆藏品信息综合管理系统正式启 用后，武汉革命博物馆将 2 万余件藏品全格式、全信息 纳入藏品资源数据库, 为博物馆发展提供从 “经验驱动” 到 “数据驱动” 的决策参照。藏品信息综合管理系统业 务版块主要实现的功能包括藏品管理、检索统计、库房 管理、台账管理、系统管理。藏品信息综合管理系统的 上线是武汉革命博物馆在馆藏管理信息化、智能化道路 上迈出的第一步，后续博物馆将基于大数据、可视化等 信息技术, 进一步构建博物馆藏品资源数字资源平台, 打造从素材采集到加工、管理一体化的综合管理系统, 构建面向观众的服务应用系统, 更大程度地发挥武汉革 命博物馆馆藏文物学术研究、社会教育、展览欣赏的综 合价值。

2020 年 2 月, 我馆三场数字展览上线: 1. 中国共产 党纪律建设历史陈列馆数字展馆突出纪律主题, 彰显时 代特点, 运用业内领先的 720 度激光采集技术, 通过多 媒体互动叠加图文、音视频等形式，让 525 件（套）文 物资料、700 余幅珍贵历史照片、200 余本近 10000 页 电子书籍可任意汶览，解说全程音画同步，全景呈现实 体展览内容, 为观众提供深度代入的浏览体验; 2. 武汉 革命博物馆全景展馆, 能够让您从空中到地面无死角地 
将场馆全貌一览无余，更可以进入到展厅内部，细细参 观陈列展览, 让您足不出户就能享受到全面可视化的高 清游览体验; 3. “日出江城一一庆祝武汉解放 70 周年 展览” 数字展馆通过 180 多件图片及实物等史料, 重现 了武汉解放波澜壮阔的辉煌历程。

近年来，武汉革命博物馆还举办了 “守望相助一家 亲—-2020 年抗击新冠疫情物证捐赠”、“以艺传情 一一抗疫艺术作品展”、“心连心 战疫情” 抗疫漫画 展、“情注笔端 以笔铸剑” 抗疫书法展、“初心・传 承——红色文物中的纪律故事” “云游都府堤” 直播等 丰富的线上展览和活动。

我馆在 2020 年全年媒体报道 294 次, 省级以上媒 体报道 106 次, 国家级媒体 41 次, 公众号 “武汉革命 博物馆”、“武汉革命博物馆宣教部” 共推送文章 161 篇, 发布微博 130 余条, 网站发布 242 条。博物馆连续 三个月跻身中博热搜榜 “全国十大热搜革命类博物馆 (纪念馆)” 名单, 成为社会各界及媒体最为关注的博 物馆之一。

\section{3. 红色文化展览策划内容和形式的创新一一 与时代同频共振}

展览要立足新时代, 坚持以习近平新时代中国特色 社会主义思想为指导, 采用新时代的语言表述, 更体现 新时代特点, 更加突出政治性、思想性、历史性、真实 性和艺术性。充分体现博物馆工作者牢固树立 “四个意 识”, 坚定 “四个自信” , 做到 “两个维护”, 与时代 同频共振, 以精品奉献人民。

武汉革命博物馆 “圆梦之路——武汉全面建成小康 社会掠影” 获评 “第五届（2020 年度）湖北省博物馆、 纪念馆六大陈列展览精品推介特别奖”。2020 年是全面 建成小康社会和 “十三五” 规划收官之年。展览通过 300 多幅图片和 158 件实物, 展示了近年来武汉在脱贫攻坚 这场 “硬仗” 中取得的不凡成绩。一组组照片, 一件件 实物, 见证了部分贫困地区的民生变化, 记录着城市发 展轨迹, 也直观反映了武汉在全面建成小康社会的历史 过程中, 在产业、健康、就业、教育、危房改造、保障、 金融、基础设施提升等方面取得的成就。

在国家文物局公布 “弘扬中华优秀传统文化、培育 社会主义核心价值观” 2021 年度主题展览推介项目名单 中, 由湖北省博物馆、武汉革命博物馆联合申报的 “人 民至上 生命至上一一抗击新冠肺炎疫情专题展览” 入 选重点推介项目, 是湖北省唯一入选项目。展览分为 6 个主题内容展区, 共 21 个单元, 展线长 1445 米, 展出 照片 1100 余张、实物展品 1000 余件（套）、视频 45 个, 设计大型场景 33 处, 互动项目 18 处, 各类展览要 素总计超过 6000 项。展览展出了 252 件来自武汉革命 博物馆的抗疫物证, 如援鄂医疗队队旗、樱花防护服、 江汉方舱医院首张胸片、非遗抗疫艺术作品等。武汉革 命博物馆参与了内容主创、展陈设计、讲解词撰写、讲 解员培训等多项重要工作, 武汉革命博物馆以专业的策 展团队、丰富的办展经验, 努力为观众呈现一场高水准 的展览, 大力弘扬伟大的抗疫精神, 生动讲述中国抗疫
故事。

今年 6 月 16 日, 经过近半年的紧张施工, 武汉革 命博物馆全新升级的 “紧急时期的艰难探索——中国共 产党第五次全国代表大会历史陈列” 正式与观众见面。 2007 年 11 月, 中共五大会址纪念馆建成开放, 至今已 走过了十多个年头, 累计接待海内外观众近 2000 万人 次, 已成为武汉市一张亮丽的红色文化名片。近年来, 随着党史研究的不断深入, 越来越多的珍贵史料和文物 相继被发现, 无论是对展览内容、表现形式还是观众服 务都提出了更高的要求。本次改陈展示面积从 660 平方 米增加到 1100 平方米, 展出历史图片 300 余幅, 上展 文物资料 180 余件/套, 其中珍贵文物 29 件。原展览中 因展线不足而无法详尽展现的五大会议代表等重点展 项有了更大的展示空间, 能更好更完整地诠释展览主 题。展览既依托旧址办展, 增强年代代入感, 又在形式 设计上运用全新思维, 通过雕塑、场景、微缩景观、多 媒体、艺术品、VR、AR 等多维度展示手法的综合运用, 提升艺术表现力和感染力, 达到最佳观展效果, 增强观 众沉浸式观展的体验感和参与感 [4]。展览被中宣部和 国家文物局评为 “庆祝中国共产党成立 100 周年精品展 览”。

为庆祝中国共产党成立一百周年, 展示一百年来党 领导武汉人民进行革命、建设、改革、复兴征程中所取 得的各项成就, 我馆举办了 “英雄城市 - 百年荣光一庆祝中国共产党成立 100 周年武汉专题展”。展览共选 用 359 张历史照片、132 件 (套) 上展实物, 其中珍贵 文物 12 件（套）, 全方位、多角度地展示了武汉在党的 百年奋斗史上的重要贡献和英雄城市、英雄人民走在时 代前列, 在民族复兴之路上奋勇前行的非凡历程。展览 综合运用图片、文字、多媒体、人机互动、艺术场景等 多种表现形式, 精心设计制作了 13 处辅助展项, 如 “红 色战士公墓” “九八抗洪” 等, 力图多维度纵深式展现 武汉的历史高光时刻。

\section{4. 红色文化藏品征集保护利用形式的创新一 一前瞻性的征集理念}

近年来, 武汉革命博物馆不断创新文物征集模式, 加大藏品征集力度, 现已形成红色革命见证与城市历史 见证两大类藏品体系。2020 年新冠肺炎疫情期间, 武汉 革命博物馆主动担当作为, 用责任和使命为明天而记录 今天, 足迹遍布全市各个角落, 围绕这些征集的抗疫物 证用心用情用力举办展览和活动, 开辟了革命文物征集 新路径。

一件件物品讲述着一个个感人的故事, 记录着一个 个生动的历史瞬间。为保护这些抗疫物证, 博物馆组 织专业人员对物证进行信息化采集, 改造和升级 200 余 平方米文物库房加装恒温恒湿设备。这些以“人民英雄” 张伯礼院士手书《归辞》、陈薇院士签名的首日封、金 银潭医院院长张定宇和 “重症八仙” 等签字的防护服、 “两山医院” 建设者的请战书、援鄂医疗队队旗、特殊 的机场登机牌、方舱医院的医疗器械、志愿者工作日志 等等为代表的来自抗疫一线物证, 承载了感人的抗疫故 
事，见证了生动的历史瞬间，彰显了生命至上、举国同 心、舍生忘死、尊重科学、命运与共的伟大抗疫精神。

收藏、保护与利用抗疫物证, 讲好抗疫故事, 弘扬 伟大的抗疫精神，既是博物馆人的初心和使命，更是公 众的期待。

在“2020 全国革命文物保护利用十佳案例宣传推介 活动” 中, 武汉革命博物馆 “弘扬抗疫精神 传承红色 基因一一武汉革命博物馆抗疫物证的收藏保护和利用” 项目荣获 “全国革命文物保护利用十佳案例” ，是全部 100 多个申报项目中唯一一个以抗击新冠肺炎疫情为主 题的项目。

近日, 中国国家博物馆研究馆员相瑞花在中国文物 学会、中国文物报社、四川省文物局联合举办的 “革命 文物保护利用实践与理念创新论坛” 上说到要重视革命 文物征集的前瞻性。武汉革命博物馆的征集理念和做法 值得借鉴。该馆认为, 现当代文物同样需要抢救。在馆 领导的高度重视下, 为明天收藏今天。所收藏的抗击新 冠疫情文物成为 “武汉抗疫专题展览” 中的重要展品; 所收藏的党建文物成为 “红色百年” 展中不可或缺的展 品 [5]。

红色, 是中国共产党的底色, 也是中国梦的底色, 是革命博物馆的底色。经历了抗疫斗争的武汉人民, 更 加认识红色文化的内涵, 更加珍惜红色文化的价值。武 汉革命博物馆也将更加努力, 弘扬红色文化, 传承红色 基因, 将博物馆打造成为新时代红色文化的新高地!

我国红色遗迹较多、范围分布广泛，坚持全面保护、 整体保护, 统筹推进抢救性与预防性保护、文物本体与 周边环境保护等等是当前重要课题。中央及地方积极完 善革命文物保护法律体系, 是强化革命文物保护力度的 刚性要求。2018 年 7 月, 中共中央办公厅、国务院办公 厅印发了《关于实施革命文物保护利用工程 (2018-2022 年）的意见》， 《意见》指出在新时代党和国家事业的 发展, 迫切需要加强革命文物资源整合、统筹规划和整 体保护, 迫切需要深化革命文物价值挖掘阐释传播, 迫 切需要发挥革命文物服务大局、资政育人和推动发展的 独特作用 [6]。2021 年 2 月, 国务院印发《关于新时代 支持革命老区振兴发展的意见》。《意见》明确提出, 加大对革命历史类纪念设施、遗址和英雄烈士纪念设施 的保护修缮力度, 加强革命老区县现存革命文物保护修 复和纪念设施保护修缮。支持革命历史类纪念设施、遗 址积极申报全国爱国主义教育示范基地、全国重点文物 保护单位、国家级英雄烈士纪念设施和国家级抗战纪念 设施、遗址。

习近平总书记今年 3 月对革命文物工作作出重要指 示指出, 革命文物承载党和人民英勇奋斗的光荣历史, 记载中国革命的伟大历程和感人事迹, 是党和国家的宝 贵财富, 是弘扬革命传统和革命文化、加强社会主义精 神文明建设、激发爱国热情、振奋民族精神的生动教材。 加强革命文物保护利用, 弘扬革命文化, 传承红色基因, 是全党全社会的共同责任。各级党委和政府要把革命文 物保护利用工作列入重要议事日程, 加大工作力度, 切 实把革命文物保护好、管理好、运用好, 发挥好革命文
物在党史学习教育、革命传统教育、爱国主义教育等方 面的重要作用, 激发广大干部群众的精神力量, 信心百 倍为全面建设社会主义现代化国家、实现中华民族伟大 复兴中国梦而奋斗。

\section{5. 结论}

追溯过去, 是为了更好地通往未来。党的十八大以 来, 习近平总书记在地方考察调研时多次到访革命纪念 地, 瞻仰革命历史纪念场所, 反复强调要用好红色资源, 传承好红色基因, 把红色江山世世代代传下去。我们要 深刻学习和领会习近平总书记的讲话精神把党的历史 学习好、总结好, 把党的成功经验传承好、发扬好, 让 广大党员干部和人民群众在重温党的光辉历史中汲取 宝贵经验和精神力量, 做到学史明理、学史增信、学史 崇德、学史力行。

\section{REFERENCES}

[1] Hu W, (2021.6.29) Tell a Good Red Story through Innovation and Gather strong spiritual power, China Tourism News

[2] Liu LL, (2021.5.2) The digital construction of major museums around the world is accelerating, The People's Daily

[3] Hai B, (2021.5.19) Audience Turns into "Students of Rural Education Institute" to Experience the Changing Times of revolution, Hubei Daily

[4] Liu H, (2021.6.17) Highlight the characteristics of The Times, Continuation of the Red Blood and Inherit the Red Gene, Changjiang Daily

[5] Xiang RH, (2021.7.20) A summary of "Revolutionary Cultural Relics Protection and Utilization Practice and Concept Innovation Forum", China Cultural Relics News

[6] Zhang SF, (2021.8.6) Development Trend of Protection and Utilization of Revolutionary Cultural Relics, China Cultural Relics News 